\title{
Distribution and rates of nitrogen fixation in the western tropical South Pacific Ocean constrained by nitrogen isotope budgets
}

\author{
Angela N. Knapp ${ }^{1}$, Kelly M. McCabe ${ }^{1}$, Olivier Grosso ${ }^{2}$, Nathalie Leblond ${ }^{3}$, Thierry Moutin ${ }^{2}$, and Sophie Bonnet ${ }^{4}$ \\ ${ }^{1}$ Earth, Ocean, and Atmospheric Science Dept., Florida State University, 117 N. Woodward AVE., \\ Tallahassee, FL 32306, USA \\ ${ }^{2}$ Aix-Marseille Université, CNRS, Université de Toulon, IRD, OSU Pythéas, Mediterranean Institute of Oceanography \\ (MIO), UM 110, 13288, Marseille, France \\ ${ }^{3}$ Observatoire Océanologique de Villefranche, Laboratoire d'Océanographie de Villefranche, UMR 7093, \\ Villefranche-sur-mer, France \\ ${ }^{4}$ Aix-Marseille Université, CNRS, Université de Toulon, IRD, OSU Pythéas, Mediterranean Institute of Oceanography \\ (MIO), UM 110, 98848 Nouméa, New Caledonia
}

Correspondence: Angela N. Knapp (anknapp@fsu.edu)

Received: 29 December 2017 - Discussion started: 10 January 2018

Revised: 17 April 2018 - Accepted: 18 April 2018 - Published: 4 May 2018

\begin{abstract}
Constraining the rates and spatial distribution of dinitrogen $\left(\mathrm{N}_{2}\right)$ fixation fluxes to the ocean informs our understanding of the environmental sensitivities of $\mathrm{N}_{2}$ fixation as well as the timescale over which the fluxes of nitrogen $(\mathrm{N})$ to and from the ocean may respond to each other. Here we quantify rates of $\mathrm{N}_{2}$ fixation as well as its contribution to export production along a zonal transect in the western tropical South Pacific (WTSP) Ocean using N isotope (" $\delta{ }^{15} \mathrm{~N}$ ") budgets. Comparing measurements of water column nitrate + nitrite $\delta^{15} \mathrm{~N}$ with the $\delta^{15} \mathrm{~N}$ of sinking particulate $\mathrm{N}$ at a western, central, and eastern station, these $\delta^{15} \mathrm{~N}$ budgets indicate high, modest, and low rates of $\mathrm{N}_{2}$ fixation at the respective stations. The results also imply that $\mathrm{N}_{2}$ fixation supports exceptionally high, i.e. $\geq 50 \%$, of export production at the western and central stations, which are also proximal to the largest iron sources. These geochemically based rates of $\mathrm{N}_{2}$ fixation are equal to or greater than those previously reported in the tropical North Atlantic, indicating that the WTSP Ocean has the capacity to support globally significant rates of $\mathrm{N}_{2}$ fixation, which may compensate for $\mathrm{N}$ removal in the oxygen-deficient zones of the eastern tropical Pacific.
\end{abstract}

\section{Introduction}

The primary source of nitrogen $(\mathrm{N})$ to the ocean is the biologically mediated reduction of dinitrogen $\left(\mathrm{N}_{2}\right)$ gas to ammonia, which is then assimilated into the biomass of the organisms carrying out this process, known as diazotrophs (Gruber, 2004). While the distribution and rates of this process in the ocean play a central role in regulating the fertility and community structure of marine ecosystems, these firstorder properties of marine $\mathrm{N}_{2}$ fixation remain poorly constrained. Historically, the highest rates of $\mathrm{N}_{2}$ fixation in the global ocean have been associated with the tropical North Atlantic (Mahaffey et al., 2005; Sohm et al., 2011). The high ${ }^{15} \mathrm{~N}_{2}$ incubation-based $\mathrm{N}_{2}$ fixation rates observed in the tropical Atlantic (Luo et al., 2012) are consistent with both the preference of diazotrophs for warm waters (Breitbarth et al., 2007; Stal, 2009) as well as the high atmospheric dust flux to the region (Mahowald et al., 2009; Prospero, 1996) that helps fulfil the high iron requirement of the enzyme, nitrogenase, carrying out $\mathrm{N}_{2}$ fixation (Berman-Frank et al., 2001; Kustka et al., 2003). Additionally, the elevated ratio of nitrate $\left(\mathrm{NO}_{3}^{-}\right)$to phosphate $\left(\mathrm{PO}_{4}^{3-}\right)$ concentrations (Gruber and Sarmiento, 1997) and low $\delta^{15} \mathrm{~N}^{-\mathrm{NO}_{3}^{-}}$(Knapp et al., 2008) in the upper thermocline of the North Atlantic are attributed to high regional $\mathrm{N}_{2}$ fixation rates and have supported the hypothesis that iron availability plays a key role in regulating the spatial distribution of $\mathrm{N}_{2}$ fixation in the ocean (Moore et 
al., 2009; Moore and Doney, 2007) (“ $\delta^{15} \mathrm{~N}$ ”, where $\delta^{15} \mathrm{~N}=$ $\left\{\left[\left({ }^{15} \mathrm{~N} /{ }^{14} \mathrm{~N}\right)_{\text {sample }} /\left({ }^{15} \mathrm{~N} /{ }^{14} \mathrm{~N}\right)_{\text {reference }}\right]-1\right\} \times 1000$, with atmospheric $\mathrm{N}_{2}$ as the reference).

While the highest inputs of $\mathrm{N}$ to the ocean have traditionally been associated with the North Atlantic, it has also been argued that this association results from the significant sampling bias in favour of the tropical Atlantic (Sohm et al., 2011), with large regions of the South Pacific and Indian Ocean under-sampled with respect to direct $\mathrm{N}_{2}$ fixation rate measurements (Luo et al., 2012). More recently, the eastern tropical South Pacific (ETSP) has seen increased sampling due to nutrient distribution-based modelling predictions that the highest global $\mathrm{N}_{2}$ fixation rates would be found in surface waters above and adjacent to oxygen-deficient zones (ODZs), where significant phosphorus $(\mathrm{P})$ would be available to support $\mathrm{N}_{2}$ fixation (Deutsch et al., 2007). However, field campaigns have found exceedingly low rates of $\mathrm{N}_{2}$ fixation in the ETSP gyre (Knapp et al., 2016a; Raimbault and Garcia, 2008; Moutin et al., 2008), which have been attributed to limited iron availability (Dekaezemacker et al., 2013). Consequently, existing measurements indicate that the dominant sinks for $\mathrm{N}$ in the ocean, benthic and water column denitrification and anaerobic ammonium oxidation, focused in the ODZs of the eastern tropical Pacific and Arabian Sea (Gruber and Galloway, 2008), are spatially segregated from the dominant $\mathrm{N}_{2}$ fixation inputs in the tropical Atlantic. This spatial decoupling of $\mathrm{N}$ inputs and outputs necessarily corresponds to a temporal decoupling, requiring the timescale of ocean circulation for $\mathrm{N}_{2}$ fixation to respond to changes in rates of denitrification, and vice versa. In spite of the apparent spatial decoupling in the modern ocean, paleoceanographic evidence indicates that $\mathrm{N}$ fluxes to and from the ocean have been closely balanced over $\geq 20 \mathrm{kyr}$, requiring feedbacks in the $\mathrm{N}$ cycle to operate on timescales shorter than ocean circulation, and thus implying a tighter spatial coupling of $\mathrm{N}$ sources and sinks (Brandes and Devol, 2002; Deutsch et al., 2004). While $\mathrm{N}$ loss in the ocean is constrained to suboxic sediments and water column ODZs, similar constraints on the location of the largest $\mathrm{N}_{2}$ fixation fluxes to the ocean are lacking, and thus the degree to which marine $\mathrm{N}$ sources and sinks have been coupled through time remains uncertain.

While prior modelling analyses emphasized the importance of iron or phosphorus in supporting $\mathrm{N}_{2}$ fixation, the most recent modelling studies reflect the importance of elevated surface temperatures, adequate iron, and the potential for low surface ocean $\mathrm{NO}_{3}^{-}: \mathrm{PO}_{4}^{3-}$ concentration ratios to support a unique ecological niche for diazotrophs (Dutkiewicz et al., 2012; Monteiro et al., 2011; Weber and Deutsch, 2014). Attention has consequently shifted to the relatively undersampled western tropical South Pacific (WTSP) Ocean, where atmospheric dust fluxes to warm surface waters are higher than in the central and eastern tropical South Pacific (Mahowald et al., 2009), and where surface ocean $\mathrm{NO}_{3}^{-}$and $\mathrm{PO}_{4}^{3-}$ concentrations and ratios are relatively ad- vantageous for diazotrophs (Moutin et al., 2005; Van Den Broeck et al., 2004). While seasonally some regions nearer to islands experience $\mathrm{PO}_{4}^{3-}$ drawdown to lower levels (e.g. Van Den Broeck et al., 2004; Moutin et al., 2018), in parts of the WTSP gyre surface ocean $\mathrm{NO}_{3}^{-}$concentrations are $\leq 0.1 \mu \mathrm{M}$ and $\mathrm{PO}_{4}^{3-}$ concentrations are $\sim 0.05$ to $0.2 \mu \mathrm{M}$ (Garcia et al., 2014), with corresponding positive $P^{*}$ values (where $P^{*}=\left[\mathrm{PO}_{4}^{3-}\right]-\left[\mathrm{NO}_{3}^{-}\right] / 16$ ) (Deutsch et al., 2007). Additionally, early remote sensing work detected significant and persistent blooms of Trichodesmium spp. in the WTSP (Dupouy et al., 2000), consistent with more recent direct observations of elevated Trichodesmium spp. abundance and $\mathrm{N}_{2}$ fixation rates observed near Melanesian islands (i.e. New Caledonia, Vanuatu, and Fiji) (Moisander et al., 2010; Shiozaki et al., 2014; Stenegren et al., 2018; Yoshikawa et al., 2015) and in the Solomon Sea (Bonnet et al., 2009, 2015; Berthelot et al., 2017). These high Trichodesmium spp. abundances and $\mathrm{N}_{2}$ fixation rates have been attributed to sea surface temperatures $>25^{\circ} \mathrm{C}$ and continuous nutrient inputs of terrigenous and volcanic origin (Labatut et al., 2014; Radic et al., 2011). Prior molecular work has also shown higher rates of $\mathrm{N}_{2}$ fixation in the WTSP at locations where surface ocean dissolved iron (DFe) concentrations were higher and where Trichodesmium spp. were less stressed for iron (Chappell et al., 2012). Together, these observations and modelling-based predictions highlight the potential for significant $\mathrm{N}_{2}$ fixation rates in regions of the WTSP where diazotrophs can meet their iron and phosphorus requirements.

Here we use geochemical tools to quantify rates of $\mathrm{N}_{2}$ fixation along a zonal transect in the WTSP where surface waters are $\geq 25^{\circ} \mathrm{C}$ and have favourable macronutrient concentrations and ratios, and where DFe concentrations are an order of magnitude higher than in the South Pacific Gyre and are mainly attributable to shallow hydrothermal input (Guieu et al., 2018). We then compare these geochemical estimates of $\mathrm{N}_{2}$ fixation rates with other metrics of $\mathrm{N}_{2}$ fixation evaluated on this cruise, as well as with the global distribution of marine $\mathrm{N}_{2}$ fixation rates.

\section{Methods}

\subsection{Sample collection}

Sampling for the Oligotrophic to UlTra-oligotrophic PACific Experiment ("OUTPACE") cruise was conducted on the R/V L'Atalante, which left Nouméa, New Caledonia, on 18 February 2015 and arrived in Papeete, Tahiti, on 2 April 2015. This cruise followed a roughly zonal transect along 18 to $19^{\circ} \mathrm{S}$ between $159^{\circ} \mathrm{E}$ and $160^{\circ} \mathrm{W}$. Details of the cruise and experimental design are described comprehensively in Moutin et al. (2017), but briefly, sediment traps were deployed at three "long-duration" (LD) stations A, B, and C (Table 1) (Fig. 1a). Water column samples were collected from Niskin bottles deployed on a CTD rosette at both 
Table 1. Location, subsurface $\mathrm{NO}_{3}^{-}+\mathrm{NO}_{2}^{-} \delta^{15} \mathrm{~N}, \mathrm{PN}_{\text {sink }} \delta^{15} \mathrm{~N}$, and $\mathrm{N}_{2}$ fixation rate and contribution to export at the OUTPACE long-duration stations.

\begin{tabular}{|c|c|c|c|c|c|c|c|}
\hline Station & $\begin{array}{r}\text { Latitude } \\
\left({ }^{\circ} \mathrm{N}\right)\end{array}$ & $\begin{array}{r}\text { Longitude } \\
\left({ }^{\circ} \mathrm{E}\right)\end{array}$ & 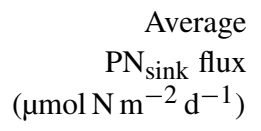 & $\begin{array}{r}150 \mathrm{~m} \text { trap } \\
\mathrm{PN}_{\text {sink }} \delta^{15} \mathrm{~N}^{*} \\
(\%)\end{array}$ & $\begin{array}{r}\text { Subsurface } \\
\mathrm{NO}_{3}^{-}+\mathrm{NO}_{2}^{-} \delta^{15} \mathrm{~N} \\
(\% \%)\end{array}$ & $\begin{array}{r}\% \text { export } \\
\mathrm{N}_{2} \text { fixation }\end{array}$ & $\begin{array}{r}\mathrm{N}_{2} \text { fixation rate } \\
\left(\mu \mathrm{mol} \mathrm{N} \mathrm{m} \mathrm{m}^{-2} \mathrm{~d}^{-1}\right)\end{array}$ \\
\hline LD A & -19.22 & 163.59 & 303 & $0.6 \pm 1$ & 7.0 to 8.4 & 80 to $83 \pm 13 \%$ & 219 to 290 \\
\hline LD B & -18.18 & -170.74 & 30 & $3.1 \pm 1$ & 7.2 to 8.3 & 50 to $56 \pm 12 \%$ & 11 to 20 \\
\hline LD C & -18.5 & -165.79 & 47 & $7.7 \pm 1$ & 7.0 to 8.4 & 0 to $8 \pm 11 \%$ & 0 to 9 \\
\hline
\end{tabular}

* Flux-weighted mean $\mathrm{PN}_{\text {sink }} \delta^{15} \mathrm{~N}$.

LD and "short-duration" (SD) stations (Fig. 1a), and water was stored at $-20^{\circ} \mathrm{C}$ in HDPE bottles for analysis on land.

\section{$2.2 \mathrm{NO}_{3}^{-}+\mathrm{NO}_{2}^{-}$concentration and $\delta^{15} \mathrm{~N}$ measurements}

The concentrations of $\mathrm{NO}_{3}^{-}+\mathrm{NO}_{2}^{-}$in water column samples collected on the OUTPACE cruise were measured by colorimetric methods (Aminot and Kerouel, 2007). The $\delta^{15} \mathrm{~N}$ of $\mathrm{NO}_{3}^{-}+\mathrm{NO}_{2}^{-}$in samples collected on the OUTPACE cruise was measured using the denitrifier method (Casciotti et al., 2002; Sigman et al., 2001), with modifications (McIlvin and Casciotti, 2011) (Fig. 1b). Typical standard deviation of the $\mathrm{NO}_{3}^{-}+\mathrm{NO}_{2}^{-} \delta^{15} \mathrm{~N}$ analyses was $\leq 0.2 \%$, with error bars for individual analyses shown in Fig. 1c.

\subsection{Sinking particulate $\mathrm{N}$ flux and $\delta^{15} \mathrm{~N}$ measurements}

Surface-tethered floating particle-interceptor traps (PPS5) were deployed on the OUTPACE cruise at 150, 330, and $520 \mathrm{~m}$ for $\sim 5$ days at stations LD A and LD B, and at 150 and $330 \mathrm{~m}$ at LD C (Moutin et al., 2017). The mass flux ("PN $\mathrm{N}_{\text {sink }}$ flux") and $\delta^{15} \mathrm{~N}$ of the $\mathrm{PN}_{\text {sink }}$ flux was determined by combustion-gas chromatography interfaced to an isotope ratio mass spectrometer at the Mediterranean Institute of Oceanography with a lower detection limit of $2.2 \mu \mathrm{g} \mathrm{N}$ and precision of $\pm 0.3 \%$ o for $80 \mu \mathrm{g}$ samples, with a precision of $\pm 1.0 \%$ for 10 to $20 \mu \mathrm{g}$ samples typical of what was collected in the sediment traps at the LD stations.

\section{$2.4 \quad \delta^{15} \mathrm{~N}$ budget calculations}

Here we compare the $\delta^{15} \mathrm{~N}$ of the two dominant sources of "new" $\mathrm{N}$ to surface waters, subsurface $\mathrm{NO}_{3}^{-}$and $\mathrm{N}_{2}$ fixation, with the $\delta^{15} \mathrm{~N}$ of the sinking particulate $\mathrm{N}\left(\mathrm{PN}_{\text {sink }}\right)$ flux to estimate the relative importance of both $\mathrm{NO}_{3}^{-}$and $\mathrm{N}_{2}$ fixation as a source of new $\mathrm{N}$ to surface waters. This approach relies on subsurface $\mathrm{NO}_{3}^{-}$and $\mathrm{N}_{2}$ fixation having distinct isotopic compositions. $\mathrm{N}_{2}$ fixation introduces new $\mathrm{N}$ to the ocean with a $\delta^{15} \mathrm{~N}$ of $\sim-1 \%$ (Carpenter et al., 1997; Hoering and Ford, 1960; Minagawa and Wada, 1986). In contrast, in the Pacific, $\mathrm{NO}_{3}^{-}$mixed up from the subsurface is impacted by water column denitrification and can have a $\mathrm{NO}_{3}^{-} \delta^{15} \mathrm{~N}>20 \%$ o (e.g. Brandes et al., 1998; Casciotti et al., 2013; Rafter and
Sigman, 2016), although as upper thermocline waters move westward in the Pacific, the very high $\mathrm{NO}_{3}^{-} \delta^{15} \mathrm{~N}$ signal is diluted and typical values are between 5 and $10 \%$ (Lehmann et al., 2018; Rafter et al., 2013). The relative importance of each source for supporting export production can be determined using the two-endmember mixing model described in Eq. (1) (" $\delta{ }^{15} \mathrm{~N}$ budget"), where the fractional importance of $\mathrm{N}_{2}$ fixation for supporting export production $(x)$ is defined as

$\mathrm{PN}_{\text {sink }} \delta^{15} \mathrm{~N}=x(-1 \%$ o $)+(1-x)\left(\mathrm{NO}_{3}^{-}+\mathrm{NO}_{2}^{-} \delta^{15} \mathrm{~N}\right)$.

Rearranging and solving for $x$ yields

$x=\frac{\mathrm{NO}_{3}^{-}+\mathrm{NO}_{2}^{-} \delta^{15} \mathrm{~N}-\mathrm{PN}_{\operatorname{sink}} \delta^{15} \mathrm{~N}}{1+\mathrm{NO}_{3}^{-}+\mathrm{NO}_{2}^{-} \delta^{15} \mathrm{~N}}$.

Multiplying the fraction of export production supported by $\mathrm{N}_{2}$ fixation $(x)$ by the $\mathrm{PN}_{\text {sink }}$ mass flux provides a timeintegrated $\mathrm{N}_{2}$ fixation rate that can be compared with ${ }^{15} \mathrm{~N}_{2}$ incubation-based $\mathrm{N}_{2}$ fixation rate measurements (Knapp et al., 2016a). Here it is hypothesized that both rates of $\mathrm{N}_{2}$ fixation and its importance for fuelling export production will be higher at stations in the western vs. central and eastern regions of the WTSP because of their closer proximity to iron sources (Guieu et al., 2018).

\section{Results}

\section{1 $\mathrm{NO}_{3}^{-}+\mathrm{NO}_{2}^{-}$concentration and $\delta^{15} \mathrm{~N}$, and $\mathbf{P N}_{\text {sink }} \delta^{15} \mathrm{~N}$}

Samples collected in the upper $70 \mathrm{~m}$ at the LD stations had $\leq 0.1 \mu \mathrm{M} \mathrm{NO} \mathrm{NO}_{3}^{-}+\mathrm{NO}_{2}^{-}$(Caffin et al., 2017) and increased with depth, consistent with prior regional observations (Garcia et al., 2014) (Fig. 1c). All nutrient concentration data are available at http://www.obs-vlfr.fr/proof/php/outpace/ outpace.php (last access: 10 April 2018). Water column $\mathrm{NO}_{3}^{-}+\mathrm{NO}_{2}^{-} \delta^{15} \mathrm{~N}$ data (Knapp et al., 2018) are available at https://www.bco-dmo.org/dataset/733237/data (last access: 11 April 2018) and show similar trends at the LD stations, with $650 \mathrm{~m} \mathrm{NO}_{3}^{-}+\mathrm{NO}_{2}^{-} \delta{ }^{15} \mathrm{~N} \sim 7 \%$, increasing to $\sim 8.5 \%$ o at $400 \mathrm{~m}$ (Fig. 1b, c) (Knapp et al., 2018), which fall within 
(a)

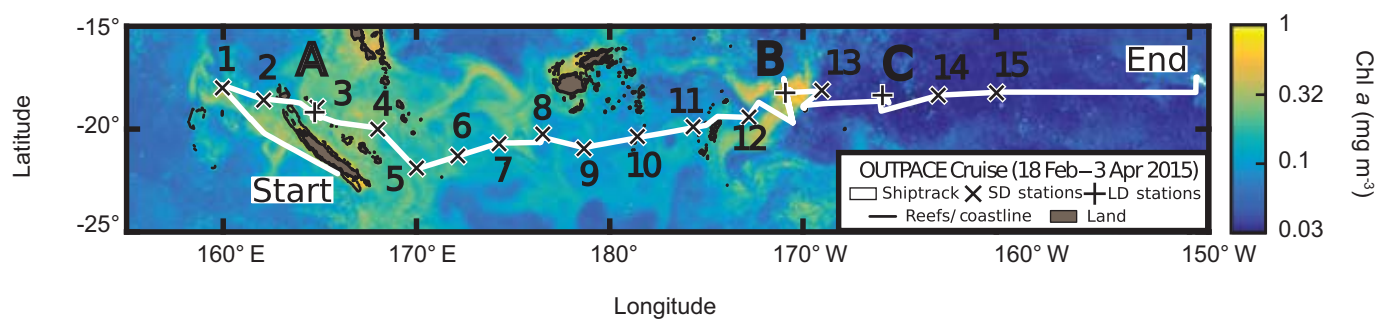

(b)
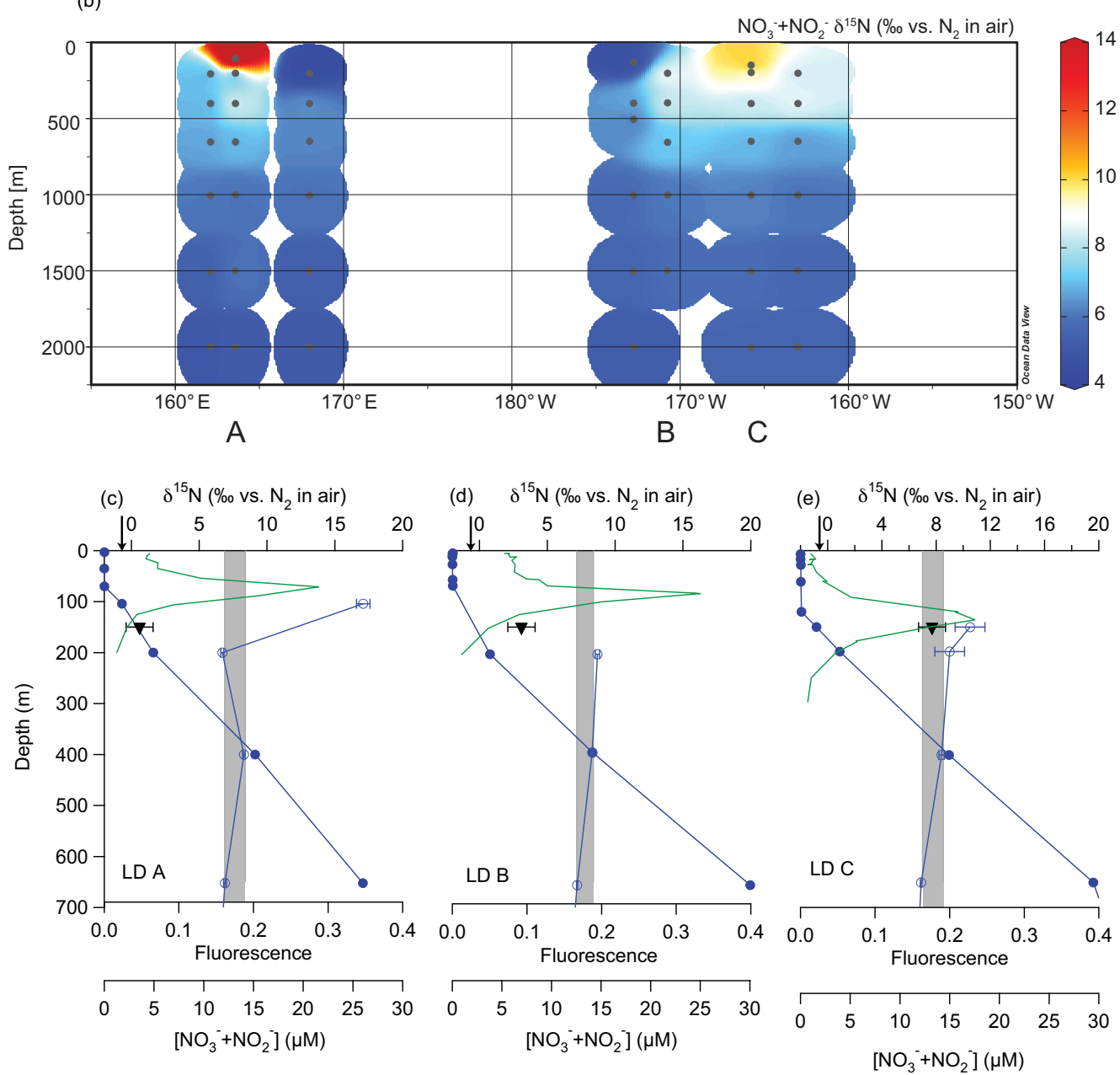

Figure 1. Map of the OUTPACE cruise with "long-duration" (LD) stations A, B, and C noted (a); water column $\mathrm{NO}_{3}^{-}+\mathrm{NO}_{2}^{-} \delta^{15} \mathrm{~N}_{\text {mea- }}$ surements from the OUTPACE cruise (b); and CTD fluorescence (green line), $\mathrm{NO}_{3}^{-}+\mathrm{NO}_{2}^{-}$concentration (filled circles), $\mathrm{NO}_{3}^{-}+\mathrm{NO}_{2}^{-} \delta^{15} \mathrm{~N}$ (open circles), and $\mathrm{PN}_{\text {sink }} \delta^{15} \mathrm{~N}$ (filled inverted triangles) from OUTPACE stations LD A (c), LD B (d), and LD C (e). Error bars represent 1 standard deviation and are smaller than the symbol size for $\mathrm{NO}_{3}^{-}+\mathrm{NO}_{2}^{-}$concentration and most $\mathrm{NO}_{3}^{-}+\mathrm{NO}_{2}^{-} \delta^{15} \mathrm{~N}$ analyses. The range of $\mathrm{NO}_{3}^{-}+\mathrm{NO}_{2}^{-} \delta^{15} \mathrm{~N}$ endmember values used for $\delta^{15} \mathrm{~N}$ budget calculations are represented by the shaded regions. The $\mathrm{N}_{2}$ fixation endmember $\delta^{15} \mathrm{~N}$ value, $-1 \%$, is represented by the arrows on the upper $x$ axis.

the range of previous regional measurements (Yoshikawa et al., 2015). The elevation of thermocline $\mathrm{NO}_{3}^{-}+\mathrm{NO}_{2}^{-} \delta^{15} \mathrm{~N}$ relative to the mean ocean $\mathrm{NO}_{3}^{-}+\mathrm{NO}_{2}^{-} \delta^{15} \mathrm{~N}$ of $5 \% \%$ is attributed to denitrification and/or anammox occurring in the ODZs of the ETSP, where thermocline $\mathrm{NO}_{3}^{-} \delta^{15} \mathrm{~N}$ can exceed
$20 \%$ (e.g. Altabet et al., 2012; Casciotti et al., 2013). The average, mass-weighted $\delta^{15} \mathrm{~N}$ of the $\mathrm{PN}_{\text {sink }}$ flux collected in the $150 \mathrm{~m}$ trap increased from the western to eastern stations, from $0.6 \pm 1.0 \%$ at $\mathrm{LD} \mathrm{A}$, to $3.1 \pm 1.0 \%$ at $\mathrm{LD} \mathrm{B}$, and to $7.7 \pm 1.0 \%$ at LD C (Table 1) (Fig. 1c). 


\subsection{Results of the $\delta^{15} \mathrm{~N}$ budget: $\mathrm{N}_{2}$ fixation rates and their contribution to export production}

Estimates of $\mathrm{N}_{2}$ fixation rates and their contribution to export production determined using $\delta^{15} \mathrm{~N}$ budgets include the quantitatively dominant fluxes of $\mathrm{N}$ into and out of the surface ocean. Here, the dominant fluxes of $\mathrm{N}$ into the surface ocean include subsurface $\mathrm{NO}_{3}^{-}$and newly fixed $\mathrm{N}$ introduced from diazotrophs, and the dominant loss term is represented by the $\mathrm{PN}_{\text {sink }}$ flux (Eq. 1). In the event that total dissolved $\mathrm{N}$ (TDN) concentrations vary in space/time, they may be included as well; however, surface ocean TDN concentrations from the OUTPACE cruise show little to no zonal gradient, and were typically between 5 and $7 \mu \mathrm{M}$ in the upper $100 \mathrm{~m}$ (Moutin et al., 2018), and so are not included in $\delta^{15} \mathrm{~N}$ budget calculations. Additionally, the importance of $\mathrm{N}$ in atmospheric deposition has recently received significant attention, especially in the northwest Pacific (e.g. Kim et al., 2014), raising the possibility that atmospheric $\mathrm{N}$ deposition might also be an important source of N in the WTSP. However, the atmospheric $\mathrm{N}$ deposition flux measured on the OUTPACE cruise, $0.2 \mu \mathrm{mol} \mathrm{N} \mathrm{m}{ }^{-2} \mathrm{~d}^{-1}$ (Caffin et al., 2017), is several orders of magnitude lower than the mass flux captured in the $150 \mathrm{~m}$ sediment traps, $30-300 \mu \mathrm{mol} \mathrm{N} \mathrm{m}{ }^{-2} \mathrm{~d}^{-1}$ (Table 1), indicating that atmospheric $\mathrm{N}$ deposition is an insignificant source of new $\mathrm{N}$ to regional surface waters, and so is neglected in our $\delta^{15} \mathrm{~N}$ budget calculations.

While gradients with depth in subsurface $\mathrm{NO}_{3}^{-}+\mathrm{NO}_{2}^{-}$ $\delta^{15} \mathrm{~N}$ at the OUTPACE LD stations are modest compared to those in the ETSP, due to the relatively low sampling resolution in the upper thermocline where $\mathrm{NO}_{3}^{-}$is likely sourced, we calculate $\delta^{15} \mathrm{~N}$ budgets using a range of $\mathrm{NO}_{3}^{-}+\mathrm{NO}_{2}^{-} \delta^{15} \mathrm{~N}$ endmember values, which are represented by the shaded regions in Fig. 1c. At each LD station, the $\mathrm{NO}_{3}^{-}+\mathrm{NO}_{2}^{-} \delta^{15} \mathrm{~N}$ lower bound is represented by the $650 \mathrm{~m}$ sample and the upper bound is represented by the $400 \mathrm{~m}$ sample. Samples collected shallower than this (i.e. $\leq 200 \mathrm{~m}$ ) either have isotopic compositions which fall within this range or show elevation in $\mathrm{NO}_{3}^{-}+\mathrm{NO}_{2}^{-} \delta^{15} \mathrm{~N}$ as the $\mathrm{NO}_{3}^{-}+\mathrm{NO}_{2}^{-}$concentration decreases, which reflects the effect of $\mathrm{NO}_{3}^{-}$assimilation. This elevation of shallow $\mathrm{NO}_{3}^{-}+\mathrm{NO}_{2}^{-} \delta^{15} \mathrm{~N}$ is commonly observed below the euphotic zone in other oligotrophic regions (Knapp et al., 2016a, 2008), and is not thought to represent the $\delta^{15} \mathrm{~N}$ of the source $\mathrm{NO}_{3}^{-}$. Using the $\mathrm{PN}_{\text {sink }} \delta^{15} \mathrm{~N}$ $( \pm 1 \%, 1 \mathrm{SD})$ and the range in subsurface $\mathrm{NO}_{3}^{-}+\mathrm{NO}_{2}^{-} \delta^{15} \mathrm{~N}$ endmember values in Eq. (2) corresponds to 80 to $83 \pm 13 \%$, 50 to $56 \pm 12 \%$, and 0 to $8 \pm 11 \%$ of export production supported by $\mathrm{N}_{2}$ fixation at stations LD A, LD B, and LD $\mathrm{C}$, respectively (Table 1). Multiplying the fractional importance of $\mathrm{N}_{2}$ fixation by the $\mathrm{PN}_{\text {sink }}$ mass flux yields a range of estimated $\mathrm{N}_{2}$ fixation rates of 219 to 290,11 to 20 , and 0 to $9 \mu \mathrm{molN} \mathrm{m} \mathrm{N}^{-2} \mathrm{~d}^{-1}$ at stations LD A, LD B, and LD $\mathrm{C}$, respectively (Table 1), where the range includes uncertainty in both the $\mathrm{PN}_{\text {sink }} \delta^{15} \mathrm{~N}$ measurement as well as the $\mathrm{NO}_{3}^{-}+\mathrm{NO}_{2}^{-} \delta^{15} \mathrm{~N}$ endmember.

\section{Discussion}

\subsection{Comparison of $\delta^{15} \mathrm{~N}$ budget results with other $\mathrm{N}_{2}$ fixation metrics from the OUTPACE cruise}

The $\mathrm{N}_{2}$ fixation rates derived from the $\delta^{15} \mathrm{~N}$ budgets described above are lower than those measured by in situ ${ }^{15} \mathrm{~N}_{2}$ incubations at the same OUTPACE stations, with depthintegrated average $\mathrm{N}_{2}$ fixation rates of $593 \pm 51,706 \pm 302$, and $59 \pm 16 \mu \mathrm{mol} \mathrm{N} \mathrm{m}{ }^{-2} \mathrm{~d}^{-1}$ at LD A, LD B, and LD C, respectively (Caffin et al., 2017). Previous work has also found lower $\delta^{15} \mathrm{~N}$ budget-derived $\mathrm{N}_{2}$ fixation rates relative to ${ }^{15} \mathrm{~N}_{2}$ incubation-based $\mathrm{N}_{2}$ fixation rates (Knapp et al., 2016a). To the extent that sediment traps under collect the export flux, the two different metrics of $\mathrm{N}_{2}$ fixation may be reconciled by multiplying $x$ from Eq. (2), the fractional importance of $\mathrm{N}_{2}$ fixation for export production, by other metrics of new or export production such as $\mathrm{O}_{2} / \mathrm{Ar}$ ratios, ${ }^{234} \mathrm{Th}$ deficits, or ${ }^{14} \mathrm{C}$ uptake rates (Knapp et al., 2016a). This explanation may reconcile the $\delta^{15} \mathrm{~N}$ budget and ${ }^{15} \mathrm{~N}_{2}$ incubation-based $\mathrm{N}_{2}$ fixation rate estimates at LD A, which differ by a factor of $\sim 2.5$, and potentially the rates at LD C as well, which, while they differ by a factor $\geq 6$, both correspond to relatively low $\mathrm{N}_{2}$ fixation rates. However, the $\delta^{15} \mathrm{~N}$ budget and ${ }^{15} \mathrm{~N}_{2}$ incubation-based $\mathrm{N}_{2}$ fixation rates observed at LD B, 11 to 20 and $706 \mu \mathrm{mol} \mathrm{N} \mathrm{m} \mathrm{m}^{-2} \mathrm{~d}^{-1}$, respectively, are more difficult to reconcile based on sediment trap under-collection alone, and may be partially attributable to variability encountered while sampling at the end of a phytoplankton bloom as well as the fate of newly fixed $\mathrm{N}$ at that station (Caffin et al., 2018; de Verneil et al., 2017). We note that the zonal trend in increasing $\mathrm{PN}_{\text {sink }} \delta^{15} \mathrm{~N}$ to the east is similar to a zonal gradient in suspended particulate $\mathrm{N}\left(\mathrm{PN}_{\text {susp }}\right) \delta^{15} \mathrm{~N}$ (Bonnet et al., 2018), suggesting that the $\delta^{15} \mathrm{~N}$ of the $\mathrm{PN}_{\text {sink }}$ observed at $\mathrm{LD} \mathrm{B}$ is consistent with other regional geochemical data. Additionally, the ${ }^{15} \mathrm{~N}_{2}$ incubation-based $\mathrm{N}_{2}$ fixation rate at LD B has relatively large error bars, resulting from observations of decreasing in situ $\mathrm{N}_{2}$ fixation rates over the course of several daily observations at LD B (Caffin et al., 2017), which may also contribute to the offset between the ${ }^{15} \mathrm{~N}_{2}$ incubation and $\delta^{15} \mathrm{~N}$ budget-based $\mathrm{N}_{2}$ fixation rate estimates. Further, the $\mathrm{PN}_{\text {sink }}$ flux collected in the $150 \mathrm{~m}$ trap at LD B, $0.030 \mathrm{mmol} \mathrm{N} \mathrm{m}^{-2} \mathrm{~d}^{-1}$, was somewhat lower than the $\mathrm{PN}_{\text {sink }}$ flux collected in the 330 and $520 \mathrm{~m}$ traps at the same station, 0.034 and $0.036 \mathrm{mmol} \mathrm{N} \mathrm{m}^{-2} \mathrm{~d}^{-1}$, respectively, which is unexpected given the more typical mass flux attenuation with depth observed at LD A and LD C, as well as elsewhere in the ocean (Martin et al., 1987). This unusual trend in mass flux with depth suggests either non-steady-state sinking flux conditions (Caffin et al., 2018) or a problem with the sediment trap sample collection at LD B. Regardless, using the ${ }^{14} \mathrm{C}$-uptake-based estimate of net $\mathrm{N}$ community production at $\mathrm{LD} \mathrm{B}, 1.91 \mathrm{mmol} \mathrm{N} \mathrm{m}^{-2} \mathrm{~d}^{-1}$, instead of the $\mathrm{PN}_{\text {sink }}$ mass flux to multiply $x$ from Eq. (2) by yields an $\mathrm{N}_{2}$ fixation rate of $2300 \mu \mathrm{mol} \mathrm{N} \mathrm{m} \mathrm{m}^{-2} \mathrm{~d}^{-1}$. These significant dispar- 
ities in productivity metrics and resulting $\mathrm{N}_{2}$ fixation rates at LD B suggests the potential for temporal decoupling of production and export and/or the underestimation of the export flux by the sediment trap, and indicate that $\mathrm{N}_{2}$ fixation rates are probably higher than those resulting from $\delta^{15} \mathrm{~N}$ budget calculations based on the mass flux to the $150 \mathrm{~m}$ trap at LD B. Regardless, we take the zonal trend in $\mathrm{PN}_{\text {sink }} \delta^{15} \mathrm{~N}$ to indicate a decreasing contribution from $\mathrm{N}_{2}$ fixation to export from the west to the east to be robust as it is consistent with both the $\mathrm{PN}_{\text {susp }} \delta \delta^{15} \mathrm{~N}$ measurements and the broad trends in ${ }^{15} \mathrm{~N}_{2}$ incubation-based $\mathrm{N}_{2}$ fixation rate estimates that decrease from the west to east.

Comparing the absolute magnitude of the $\delta^{15} \mathrm{~N}$-budgetbased $\mathrm{N}_{2}$ fixation rates with previous measurements, we find that the 219 to $290 \mu \mathrm{mol} \mathrm{N} \mathrm{m}{ }^{-2} \mathrm{~d}^{-1}$ rate estimated for LD A represents a significant $\mathrm{N}_{2}$ fixation rate relative to prior global measurements (Luo et al., 2012), in particular if it should be revised upwards to account for the under-collection of the export flux by the sediment trap. In contrast, the estimated rate range at $\mathrm{LD} \mathrm{B}, 11$ to $21 \mu \mathrm{mol} \mathrm{N} \mathrm{m}{ }^{-2} \mathrm{~d}^{-1}$, is quite low, as is the range of 0 to $9 \mu \mathrm{mol} \mathrm{N} \mathrm{m}{ }^{-2} \mathrm{~d}^{-1}$ at LD C, and both of these rates are broadly similar to the rates previously measured in the ETSP (Knapp et al., 2016a; Moutin et al., 2008; Raimbault and Garcia, 2008). Similarly, the $\delta^{15} \mathrm{~N}$ budget-based estimate of the contribution of $\mathrm{N}_{2}$ fixation to export production at LD C is low and similar to previous $\delta^{15} \mathrm{~N}$-budget measurements in the North Pacific (Casciotti et al., 2008) and North Atlantic (Altabet, 1988; Knapp et al., 2005). However, the fractional contribution of $\mathrm{N}_{2}$ fixation to export production at LD A, 80 to $83 \%$, is higher than all previous $\delta^{15} \mathrm{~N}$ budget results. The contribution of $\mathrm{N}_{2}$ fixation to export production at LD B, 50 to $57 \%$, is also notably high. While the previous $\delta^{15} \mathrm{~N}$ budgets of Karl et al. (1997) and Dore et al. (2002) found evidence for $\sim 50 \%$ of export production being supported by $\mathrm{N}_{2}$ fixation near Hawaii, newer methods capable of measuring the $\mathrm{NO}_{3}^{-}+\mathrm{NO}_{2}^{-} \delta^{15} \mathrm{~N}$ at the lower $\mathrm{NO}_{3}^{-}+\mathrm{NO}_{2}^{-}$concentrations found in the upper thermocline that represent a more realistic estimate of the endmember $\mathrm{NO}_{3}^{-}$source suggest that $\mathrm{N}_{2}$ fixation may support closer to $25 \%$ of export during the summer in the North Pacific Gyre (Bottjer et al., 2017; Casciotti et al., 2008). Consequently, the findings of 50 to $57 \%$ and 80 to $83 \%$ of export production being supported by $\mathrm{N}_{2}$ fixation at stations LD B and LD A, respectively, indicate that $\mathrm{N}_{2}$ fixation plays a significant role in supporting carbon fixation and export production in this region of the WTSP, consistent with the high $e$ ratios (up to 9.7) reported by Caffin et al. (2017). Direct export of diazotrophs has been reported by Caffin et al. (2017), but most export is likely indirect, i.e. after the transfer of diazotroph-derived $\mathrm{N}$ to non-diazotrophic plankton, which is subsequently exported (Caffin et al., 2018), as has been observed elsewhere in the WTSP (Bonnet et al., 2016; Knapp et al., 2016b).

\subsection{Environmental sensitivities of $\mathrm{N}_{2}$ fixation and the basin-scale coupling of $\mathrm{N}$ sources and sinks}

The zonal gradient in both $\mathrm{N}_{2}$ fixation rates as well as their contribution to export production in the OUTPACE study supports emerging hypotheses regarding the controls on the distribution of marine $\mathrm{N}_{2}$ fixation fluxes in the global ocean. Specifically, the low rates of $\mathrm{N}_{2}$ fixation documented in this study at LD C and in the ETSP (Knapp et al., 2016a) indicate that low $\mathrm{NO}_{3}^{-}: \mathrm{PO}_{4}^{3-}$ concentration ratios in the absence of adequate iron (Blain et al., 2008; Fitzsimmons et al., 2014) are insufficient to support significant fluxes of new $\mathrm{N}$ to the ocean. Instead, the results presented here are consistent with recent modelling work that has included both the high iron requirements of diazotrophs and the potential for low $\mathrm{NO}_{3}^{-}: \mathrm{PO}_{4}^{3-}$ concentration ratios to support elevated diazotroph abundance and $\mathrm{N}_{2}$ fixation inputs to the ocean (Dutkiewicz et al., 2012; Monteiro et al., 2011; Weber and Deutsch, 2014). Indeed, these new modelling efforts have identified the WTSP as a unique region where $\mathrm{PO}_{4}^{3-}$ concentrations are relatively high, $\mathrm{NO}_{3}^{-}$concentrations are low, and atmospheric dust fluxes provide a moderate source of iron to warm surface waters, conditions seemingly favourable for significant $\mathrm{N}_{2}$ fixation fluxes. While regions within the WTSP nearer to islands experience significant $\mathrm{PO}_{4}^{3-}$ drawdown, with seasonal $\mathrm{PO}_{4}^{3-}$ turnover times comparable to those observed in the Sargasso Sea (Van Den Broeck et al., 2004; Van Mooy et al., 2009), these modelling predictions are supported by recent reports of high regional ${ }^{15} \mathrm{~N}_{2}$ incubation-based $\mathrm{N}_{2}$ fixation rates (Bonnet et al., 2017).

However, prior to the OUTPACE cruise, our knowledge of DFe concentrations and their sources in the WTSP was limited, especially in the western and central sectors. During OUTPACE, Guieu et al. (2018) reported high DFe concentrations in the western sector of the WTSP (from $160^{\circ} \mathrm{E}$ to $165^{\circ} \mathrm{W}$, average $1.7 \mathrm{nM}$ within the photic layer), i.e. significantly $(p<0.05)$ higher than those reported in the eastern sector $\left(165-160^{\circ} \mathrm{W}\right.$, average $0.3 \mathrm{nM}$ within the photic layer). The high $\mathrm{DFe}$ concentrations measured in the west were previously undocumented and reveal several maxima $(>50 \mathrm{nM})$, suggesting significant iron inputs to this region. Guieu et al. (2018) found that atmospheric deposition in this region was too low to explain the observed DFe concentrations in the water column, and that the iron in the euphotic layer may instead derive from shallow $(\sim 500 \mathrm{~m})$ hydrothermal sources associated with the Tonga-Kermadec subduction zone.

Recent studies performed in the western end of the WTSP in the Solomon, Bismarck (Berthelot et al., 2017; Bonnet et al., 2009, 2015), and Arafura (Messer et al., 2015; Montoya et al., 2004) seas also reveal extremely high $\mathrm{N}_{2}$ fixation rates ( $>600 \mu \mathrm{molN} \mathrm{m} \mathrm{N}^{-2} \mathrm{~d}^{-1}$ ), indicating that high $\mathrm{N}_{2}$ fixation rates have been found over a significant region of the WTSP, extending west to east from Australia to Tonga and north to south from the Equator to 25 to $30^{\circ} \mathrm{S}$, or $\sim 13 \times 10^{6} \mathrm{~km}^{2}$ 
(i.e. $\sim 20 \%$ of the South Pacific Ocean area). These significant $\mathrm{N}$ inputs may offset the $\mathrm{N}$ loss occurring in the ODZs of the eastern tropical Pacific. The ability for marine $\mathrm{N}$ inputs and outputs to compensate for each other within the same ocean basin corresponds to a spatial and thus temporal coupling on the scale of years to decades, consistent with the paleoceanographic record (Brandes and Devol, 2002; Deutsch et al., 2004; Weber and Deutsch, 2014), and represents an intermediate view of the distribution of global marine $\mathrm{N}_{2}$ fixation fluxes consistent with that proposed by Weber and Deutsch (2014), where iron availability controls local $\mathrm{N}_{2}$ fixation rates but phosphorus availability regulates basin-scale $\mathrm{N}_{2}$ fixation rates (Moutin et al., 2008, 2018).

\section{Conclusions}

The goal of this study was to address the question: do regions other than the tropical Atlantic contribute significantly to global $\mathrm{N}_{2}$ fixation fluxes? While our results should be taken as a "snapshot" view that cannot necessarily be scaled up to annual fluxes, at stations proximal to iron sources, geochemically derived $\mathrm{N}_{2}$ fixation rates of 219 to $290 \mu \mathrm{mol} \mathrm{N} \mathrm{m}{ }^{-2} \mathrm{~d}^{-1}$ were observed, and could potentially represent a lower bound of $\mathrm{N}_{2}$ fixation rates due to the potential under-collection of the $\mathrm{PN}_{\text {sink }}$ flux by sediment traps. Moreover, at stations LD A and LD B, separated by $\sim 27^{\circ}$ longitude, $\mathrm{N}_{2}$ fixation was found to support $>50 \%$ of export production, a finding that has not been replicated elsewhere with sensitive $\mathrm{NO}_{3}^{-}+\mathrm{NO}_{2}^{-} \delta^{15} \mathrm{~N}$ methods to our knowledge. Together with similar findings from ${ }^{15} \mathrm{~N}_{2}$ uptake experiments, these results suggests that $\mathrm{N}_{2}$ fixation can support a significant fraction of export production over a large region of the WTSP. At the eastern station most distant from iron sources, both rates and the contribution of $\mathrm{N}_{2}$ fixation to export production were low, $\sim 0$ to $9 \mu \mathrm{mol} \mathrm{N} \mathrm{m}{ }^{-2} \mathrm{~d}^{-1}$ and 0 to $8 \%$, respectively, similar to previous measurements in the ETSP where diazotrophs may also be challenged by iron availability (Dekaezemacker et al., 2013; Knapp et al., 2016a; Moutin et al., 2008). Significant $\mathrm{N}_{2}$ fixation fluxes in the WTSP may provide a means of balancing $\mathrm{N}$ loss occurring in the ODZs of the eastern tropical Pacific, and thus may help reconcile the paleoceanographic record requiring $\mathrm{N}$ inputs and losses to balance each other on timescales shorter than ocean circulation (Dutkiewicz et al., 2012; Monteiro et al., 2011; Weber and Deutsch, 2014).
Data availability. All data and metadata are available at the French INSU/CNRS LEFE CYBER database (scientific coordinator: Hervé Claustre; data manager and webmaster: Catherine Schmechtig) at the following web address: http://www.obs-vlfr.fr/ proof/php/outpace/outpace.php. The data supporting the conclusions of this paper may be obtained at the BCO-DMO database https://www.bco-dmo.org/dataset/733237 (Knapp et al., 2018).

Competing interests. The authors declare that they have no conflict of interest.

Special issue statement. This article is part of the special issue "Interactions between planktonic organisms and biogeochemical cycles across trophic and $\mathrm{N}_{2}$ fixation gradients in the western tropical South Pacific Ocean: a multidisciplinary approach (OUTPACE experiment)". It is not associated with a conference.

Acknowledgements. This is a contribution of the OUTPACE (Oligotrophy to Ultra-oligoTrophy PACific Experiment) project (https://outpace.mio.univ-amu.fr/) funded by the French national research agency (ANR-14-CE01-0007-01), the LEFE-CyBER programme (CNRS-INSU), the GOPS programme (IRD) and the CNES. Funding for the contribution of Angela N. Knapp and Kelly M. McCabe was provided by the U.S. National Science Foundation OCE \#1537314. The OUTPACE cruise (https://doi.org/10.17600/15000900) was managed by the MIO (OSU Institut Pytheas, AMU) from Marseilles (France). The authors thank the crew of the $\mathrm{R} / \mathrm{V}$ L'Atalante for outstanding shipboard operation. Gilles Rougier and Marc Picheral are warmly thanked for their efficient help in CTD rosette management and data processing, as is Catherine Schmechtig for the LEFE CYBER database management and Carlos Miranda for analytical assistance.

Edited by: Emilio Marañón

Reviewed by: two anonymous referees

\section{References}

Altabet, M. A.: Variations in Nitrogen Isotopic Composition between Sinking and Suspended Particles - Implications for Nitrogen Cycling and Particle Transformation in the Open Ocean, Deep-Sea Res. Pt. I, 35, 535-554, 1988.

Altabet, M. A., Ryabenko, E., Stramma, L., Wallace, D. W. R., Frank, M., Grasse, P., and Lavik, G.: An eddy-stimulated hotspot for fixed nitrogen-loss from the Peru oxygen minimum zone, Biogeosciences, 9, 4897-4908, https://doi.org/10.5194/bg9-4897-2012, 2012.

Aminot, A. and Kerouel, R.: Dosage automatique des nutriments dans les eaux marines: méthodes en flux continu, Ifremer, Plouzanne, France, 2007.

Berman-Frank, I., Cullen, J. T., Shaked, Y., Sherrell, R. M., and Falkowski, P. G.: Iron availability, cellular iron quotas, and nitrogen fixation in Trichodesmium, Limnol. Oceanogr., 46, 12491260, 2001. 
Berthelot, H., Benavides, M., Moisander, P. H., Grosso, O., and Bonnet, S.: High nitrogen fixation rates in the particulate and dissolved pools in the Western Tropical Pacific (Solomon and Bismarck Seas), Geophys. Res. Lett., 44, 8414-8423, 2017.

Blain, S., Bonnet, S., and Guieu, C.: Dissolved iron distribution in the tropical and sub tropical South Eastern Pacific, Biogeosciences, 5, 269-280, https://doi.org/10.5194/bg-5-2692008, 2008.

Bonnet, S., Biegala, I. C., Dutrieux, P., Slemons, L. O., and Capone, D. G.: Nitrogen fixation in the western equatorial Pacific: Rates, diazotrophic cyanobacterial size class distribution, and biogeochemical significance, Global Biogeochem. Cy., 23, 1-13, 2009.

Bonnet, S., Rodier, M., Turk, K., Germineaud, C., Menkes, C., Ganachaud, A., Cravatte, S., Raimbault, P., Campbell, E., Quéroué, F., Sarthou, G., Desnues, A., Maes, C., and Eldin, G.: Contrasted geographical distribution of $\mathrm{N}_{2}$ fixation rates and nifH phylotypes in the Coral and Solomon Seas (South-Western Pacific) during austral winter conditions, Global Biogeochem. Cy., 29, 1874-1892, 2015.

Bonnet, S., Berthelot, H., Turk-Kubo, K., Fawcett, S., Rahav, E., L'Helguen, S., and Berman-Frank, I.: Dynamics of $\mathrm{N}_{2}$ fixation and fate of diazotroph-derived nitrogen in a low-nutrient, low-chlorophyll ecosystem: results from the VAHINE mesocosm experiment (New Caledonia), Biogeosciences, 13, 2653-2673, https://doi.org/10.5194/bg-13-2653-2016, 2016.

Bonnet, S., Caffin, M., Berthelot, H., and Moutin, T.: Hot spot of $\mathrm{N}_{2}$ fixation in the western tropical South Pacific pleads for a spatial decoupling between $\mathrm{N}_{2}$ fixation and denitrification, P. Natl. Acad. Sci. USA, 114, E2800-E2801, 2017.

Bonnet, S., Caffin, M., Berthelot, H., Grosso, O., Guieu, C., and Moutin, T.: Contribution of dissolved and particulate fractions to the Hot Spot of $\mathrm{N}_{2}$ fixation in the Western Tropical South Pacific Ocean (OUTPACE cruise), Biogeosciences, submitted, 2018.

Bottjer, D., Dore, J. E., Karl, D. M., Letelier, R. M., Mahaffey, C., Wilson, S. T., Zehr, J., and Church, M. J.: Temporal variability of nitrogen fixation and particulate nitrogen export at Station ALOHA, Limnol. Oceanogr., 62, 200-216, 2017.

Brandes, J. A. and Devol, A. H.: A global marine-fixed nitrogen isotopic budget: Implications for Holocene nitrogen cycling, Global Biogeochem. Cy., 16, 2002.

Brandes, J. A., Devol, A. H., Yoshinari, T., Jayakumar, D. A., and Naqvi, S. W. A.: Isotopic composition of nitrate in the central Arabian Sea and eastern tropical North Pacific: A tracer for mixing and nitrogen cycles, Limnol. Oceanogr., 43, 1680-1689, 1998.

Breitbarth, E., Oschlies, A., and LaRoche, J.: Physiological constraints on the global distribution of Trichodesmium - effect of temperature on diazotrophy, Biogeosciences, 4, 53-61, https://doi.org/10.5194/bg-4-53-2007, 2007.

Caffin, M., Moutin, T., Foster, R. A., Bouruet-Aubertot, P., Doglioli, A. M., Berthelot, H., Grosso, O., Helias-Nunige, S., Leblond, N., Gimenez, A., Petrenko, A. A., de Verneil, A., and Bonnet, S.: Nitrogen budgets following a Lagrangian strategy in the Western Tropical South Pacific Ocean: the prominent role of $\mathrm{N}_{2}$ fixation (OUTPACE cruise), Biogeosciences Discuss., https://doi.org/10.5194/bg-2017-468, in review, 2017.

Caffin, M., Berthelot, H., Cornet-Barthaux, V., and Bonnet, S.: Transfer of diazotroph-derived nitrogen to the planktonic food web across gradients of $\mathrm{N}_{2}$ fixation activity and diversity in the Western Tropical South Pacific, Biogeosciences Discuss., https://doi.org/10.5194/bg-2017-572, in review, 2018.

Carpenter, E. J., Harvey, H. R., Fry, B., and Capone, D. G.: Biogeochemical tracers of the marine cyanobacterium Trichodesmium, Deep-Sea Res. Pt. I, 44, 27-38, 1997.

Casciotti, K. L., Sigman, D. M., Hastings, M. G., Bohlke, J. K., and Hilkert, A.: Measurement of the oxygen isotopic composition of nitrate in seawater and freshwater using the denitrifier method, Anal. Chem., 74, 4905-4912, 2002.

Casciotti, K. L., Trull, T. W., Glover, D. M., and Davies, D.: Constraints on nitrogen cycling at the subtropical North Pacific Station ALOHA from isotopic measurements of nitrate and particulate nitrogen, Deep-Sea Res. Pt. II, 55, 1661-1672, 2008.

Casciotti, K. L., Buchwald, C., and McIlvin, M.: Implications of nitrate and nitrite isotopic measurements for the mechanisms of nitrogen cycling in the Peru oxygen deficient zone, Deep-Sea Res. Pt I, 80, 78-93, 2013.

Chappell, P. D., Moffett, J. W., Hynes, A. M., and Webb, E. A.: Molecular evidence of iron limitation and availability in the global diazotroph Trichodesmium, ISME Journal, 6, 1728-1739, 2012.

Dekaezemacker, J., Bonnet, S., Grosso, O., Moutin, T., Bressac, M., and Capone, D. G.: Evidence of active dinitrogen fixation in surface waters of the eastern tropical South Pacific during El Niño and La Niña events and evaluation of its potential nutrient controls, Global Biogeochem. Cy., 27, 768-779, 2013.

Deutsch, C., Sigman, D. M., Thunell, R. C., Meckler, A. N., and Haug, G. H.: Isotopic constraints on glacial/interglacial changes in the oceanic nitrogen budget, Global Biogeochem. Cy., 18, GB4012, https://doi.org/10.1029/2003GB002189, 2004.

Deutsch, C., Sarmiento, J. L., Sigman, D. M., Gruber, N., and Dunne, J. P.: Spatial coupling of nitrogen inputs and losses in the ocean, Nature, 445, 163-167, 2007.

de Verneil, A., Rousselet, L., Doglioli, A. M., Petrenko, A. A., and Moutin, T.: The fate of a southwest Pacific bloom: gauging the impact of submesoscale vs. mesoscale circulation on biological gradients in the subtropics, Biogeosciences, 14, 3471-3486, https://doi.org/10.5194/bg-14-3471-2017, 2017.

Dore, J. E., Brum, J. R., Tupas, L. M., and Karl, D. M.: Seasonal and interannual variability in sources of nitrogen supporting export in the oligotrophic subtropical North Pacific Ocean, Limnol. Oceanogr., 47, 1595-1607, 2002.

Dupouy, C., Neveux, J., Subramaniam, A., Mulholland, M. R., Montoya, J. P., Campbell, L., Carpenter, E. J., and Capone, D. G.: Satellite captures trichodesmium blooms in the southwestern tropical Pacific, EOS T. Am. Geophys. Un., 81, 13-16, 2000.

Dutkiewicz, S., Ward, B. A., Monteiro, F., and Follows, M. J.: Interconnection of nitrogen fixers and iron in the Pacific Ocean: Theory and numerical simulations, Global Biogeochem. Cy., 26, GB1012, https://doi.org/10.1029/2011GB004039, 2012.

Fitzsimmons, J. N., Boyle, E. A., and Jenkins, W. J.: Distal transport of dissolved hydrothermal iron in the deep South Pacific Ocean, P. Natl. Acad. Sci. USA, 111, 16654-16661, 2014.

Garcia, H. E., Locarnini, R. A., Boyer, T. P., Antonov, J. I., Baranova, O. K., Zweng, M. M., Reagan, J. R., and Johnson, D. R.: World Ocean Atlas 2013, vol. 4, Dissolved Inorganic Nutrients (phosphate, nitrate, silicate), NOAA, Silver Spring, MD, 2014.

Gruber, N.: The dynamics of the marine nitrogen cycle and its influence on atmospheric $\mathrm{CO}_{2}$ variations, in: The Ocean Carbon 
Cycle and Climate, edited by: Follows, M. and Oguz, T., Kluwer Academic, Dordrecht, 2004.

Gruber, N. and Galloway, J. N.: An Earth-system perspective of the global nitrogen cycle, Nature, 451, 293-296, 2008.

Gruber, N. and Sarmiento, J. L.: Global patterns of marine nitrogen fixation and denitrification, Global Biogeochem. Cy., 11, 235266, 1997.

Guieu, C., Bonnet, S., Petrenko, A., Menkes, C., Chavaganc, V., Desboeufs, K., and Moutin, T.: Iron from a submarine source impacts the productive layer of the Western Tropical South Pacific, Sci. Rep.-UK, in review, 2018.

Hoering, T. C. and Ford, H. T.: The Isotope Effect in the Fixation of Nitrogen by Azotobacter, J. Am. Chem. Soc., 82, 376-378, 1960.

Karl, D., Letelier, R., Tupas, L., Dore, J., Christian, J., and Hebel, D.: The role of nitrogen fixation in biogeochemical cycling in the subtropical North Pacific Ocean, Nature, 388, 533-538, 1997.

Kim, I.-N., Lee, K., Gruber, N., Karl, D. M., Bullister, J. L., Yang, S., and Kim, T.-W.: Increasing anthropogenic nitrogen in the North Pacific Ocean, Science, 346, 1102-1106, 2014.

Knapp, A. N., Sigman, D. M., and Lipschultz, F.: N isotopic composition of dissolved organic nitrogen and nitrate at the Bermuda Atlantic time-series study site, Global Biogeochem. Cy., 19, GB1018, https://doi.org/10.1029/2004GB002320, 2005.

Knapp, A. N., DiFiore, P. J., Deutsch, C., Sigman, D. M., and Lipschultz, F.: Nitrate isotopic composition between Bermuda and Puerto Rico: Implications for $\mathrm{N}_{2}$ fixation in the Atlantic Ocean, Global Biogeochem. Cy., 22, GB3014, https://doi.org/10.1029/2007GB003107, 2008.

Knapp, A. N., Casciotti, K. L., Berelson, W. M., Prokopenko, M. G., and Capone, D. G.: Low rates of nitrogen fixation in eastern tropical South Pacific surface waters, P. Natl. Acad. Sci. USA, 113, 4398-4403, 2016a.

Knapp, A. N., Fawcett, S. E., Martínez-Garcia, A., Leblond, N., Moutin, T., and Bonnet, S.: Nitrogen isotopic evidence for a shift from nitrate- to diazotroph-fueled export production in the VAHINE mesocosm experiments, Biogeosciences, 13, 46454657, https://doi.org/10.5194/bg-13-4645-2016, 2016 b.

Knapp, A. N., McCabe, K., Grosso, O., Leblond, N., Moutin, T., and Bonnet, S.: Water column nitrate + nitrite $\delta^{15} \mathrm{~N}$ measurements from R/V L'Atalante in the southwest Pacific Ocean between New Caledonia and Tahiti from February to March 2015, Biological and Chemical Oceanography Data Management Office (BCO-DMO), available at: https://www.bco-dmo. org/dataset/733237 (last access: 27 April 2018), 2018.

Kustka, A. B., Sanudo-Wilhelmy, S. A., Carpenter, E. J., Capone, D., Burns, J., and Sunda, W. G.: Iron requirements for dinitrogenand ammonium-supported growth in cultures of Trichodesmium (IMS 101): Comparison with nitrogen fixation rates and iron: carbon ratios of field populations, Limnol. Oceanogr., 48, 18691884, 2003.

Labatut, M., Lacan, F., Pradoux, C., Chmeleff, J., Radic, A., Murray, J. W., Poitrasson, F., Johansen, A. M., and Thil, F.: Iron sources and dissolved-particulate interactions in the seawater of the Western Equatorial Pacific, iron isotope perspectives, Global Biogeochem. Cy., 28, 1044-1065, https://doi.org/10.1002/2014GB004928, 2014.

Lehmann, N., Granger, J., Kienast, M., Brown, K. S., Rafter, R. A., Martínez-Méndez, G., and Mohtadi, M.: Isotopic
Evidence for the Evolution of Subsurface Nitrate in the Western Equatorial Pacific, J. Geophys. Res.-Oceans, https://doi.org/10.1002/2017JC013527, online first, 2018.

Luo, Y.-W., Doney, S. C., Anderson, L. A., Benavides, M., BermanFrank, I., Bode, A., Bonnet, S., Boström, K. H., Böttjer, D., Capone, D. G., Carpenter, E. J., Chen, Y. L., Church, M. J., Dore, J. E., Falcón, L. I., Fernández, A., Foster, R. A., Furuya, K., Gómez, F., Gundersen, K., Hynes, A. M., Karl, D. M., Kitajima, S., Langlois, R. J., LaRoche, J., Letelier, R. M., Marañón, E., McGillicuddy Jr., D. J., Moisander, P. H., Moore, C. M., Mouriño-Carballido, B., Mulholland, M. R., Needoba, J. A., Orcutt, K. M., Poulton, A. J., Rahav, E., Raimbault, P., Rees, A. P., Riemann, L., Shiozaki, T., Subramaniam, A., Tyrrell, T., Turk-Kubo, K. A., Varela, M., Villareal, T. A., Webb, E. A., White, A. E., Wu, J., and Zehr, J. P.: Database of diazotrophs in global ocean: abundance, biomass and nitrogen fixation rates, Earth Syst. Sci. Data, 4, 47-73, https://doi.org/10.5194/essd-447-2012, 2012.

Mahaffey, C., Michaels, A. F., and Capone, D. G.: The conundrum of marine $\mathrm{N}_{2}$ fixation, Am. J. Sci., 305, 546-595, 2005.

Mahowald, N. M., Engelstaedter, S., Luo, C., Sealy, A., Artaxo, P., Benitez-Nelson, C., Bonnet, S., Chen, Y., Chuang, P. Y., Cohen, D. D., Dulac, F., Herut, B., Johansen, A. M., Kubilay, N., Losno, R., Maenhaut, W., Paytan, A., Prospero, J. A., Shank, L. M., and Siefert, R. L.: Atmospheric Iron Deposition: Global Distribution, Variability, and Human Perturbations, Ann Rev Mar Sci., 1, 245278, 2009.

Martin, J. H., Knauer, G. A., Karl, D. M., and Broenkow, W. W.: Vertex - Carbon Cycling in the Northeast Pacific, Deep-Sea Res. Pt I, 34, 267-285, 1987.

McIlvin, M. R. and Casciotti, K. L.: Technical Updates to the Bacterial Method for Nitrate Isotopic Analyses, Anal. Chem., 83, 1850-1856, 2011.

Messer, L. F., Mahaffey, C., M Robinson, C., Jeffries, T. C., Baker, K. G., Bibiloni Isaksson, J., Ostrowski, M., Doblin, M. A., Brown, M. V., and Seymour, J. R.: High levels of heterogeneity in diazotroph diversity and activity within a putative hotspot for marine nitrogen fixation, ISME J., 10, 1499-1513, https://doi.org/10.1038/ismej.2015.205, 2015.

Minagawa, M. and Wada, E.: Nitrogen Isotope Ratios of Red Tide Organisms in the East-China-Sea - a Characterization of Biological Nitrogen-Fixation, Mar. Chem., 19, 245-259, 1986.

Moisander, P. H., Beinart, R. A., Hewson, I., White, A. E., Johnson, K. S., Carlson, C. A., Montoya, J. P., and Zehr, J. P.: Unicellular Cyanobacterial Distributions Broaden the Oceanic $N_{2}$ Fixation Domain, Science, 327, 1512-1514, 2010.

Monteiro, F. M., Dutkiewicz, S., and Follows, M. J.: Biogeographical controls on the marine nitrogen fixers, Global Biogeochem. Cy., 25, GB2003, https://doi.org/10.1029/2010GB003902, 2011.

Montoya, J. P., Holl, C. M., Zehr, J. P., Hansen, A., Villareal, T. A., and Capone, D. G.: High rates of $\mathrm{N}_{2}$ fixation by unicellular diazotrophs in the oligotrophic Pacific Ocean, Nature, 430, 1027-1031, 2004.

Moore, J. K. and Doney, S. C.: Iron availability limits the ocean nitrogen inventory stabilizing feedbacks between marine denitrification and nitrogen fixation, Global Biogeochem. Cy., 21, GB2001, https://doi.org/10.1029/2006GB002762, 2007.

Moore, C. M., Mills, M. M., Achterberg, E. P., Geider, R. J., LaRoche, J., Lucas, M. I., McDonagh, E. L., Pan, X., Poulton, A. 
J., Rijkenberg, M. J. A., Suggett, D. J., Ussher, S. J., and Woodward, E. M. S.: Large-scale distribution of Atlantic nitrogen fixation controlled by iron availability, Nat. Geosci., 2, 867-871, 2009.

Moutin, T., Van Den Broeck, N., Beker, B., Dupouy, C., Rimmelin, P., and Le Bouteiller, A.: Phosphate availability controls Trichodesmium spp. biomass in the SW Pacific Ocean, Mar. Ecol. Prog. Ser., 297, 15-21, 2005.

Moutin, T., Karl, D. M., Duhamel, S., Rimmelin, P., Raimbault, P., Van Mooy, B. A. S., and Claustre, H.: Phosphate availability and the ultimate control of new nitrogen input by nitrogen fixation in the tropical Pacific Ocean, Biogeosciences, 5, 95-109, https://doi.org/10.5194/bg-5-95-2008, 2008.

Moutin, T., Doglioli, A. M., de Verneil, A., and Bonnet, S.: Preface: The Oligotrophy to the UlTra-oligotrophy PACific Experiment (OUTPACE cruise, 18 February to 3 April 2015), Biogeosciences, 14, 3207-3220, https://doi.org/10.5194/bg-143207-2017, 2017.

Moutin, T., Wagener, T., Caffin, M., Fumenia, A., Gimenez, A., Baklouti, M., Bouruet-Aubertot, P., Pujo-Pay, M., Leblanc, K., Lefevre, D., Helias Nunige, S., Leblond, N., Grosso, O., and de Verneil, A.: Nutrient availability and the ultimate control of the biological carbon pump in the Western Tropical South Pacific Ocean, Biogeosciences Discuss., https://doi.org/10.5194/bg-2017-565, in press, 2018.

Prospero, J. M.: Saharan dust transport over the North Atlantic Ocean and Mediterranean: An overview, in: Impact of Desert Dust across the Mediterranean, Environmental Science and Technology Library, 1996.

Radic, A., Lacan, F., and Murray, J. W.: Iron isotopes in the seawater of the equatorial Pacific Ocean: New constraints for the oceanic iron cycle, Earth Planet. Sc. Lett., 306, 1-10, 2011.

Rafter, P. A. and Sigman, D. M.: Spatial distribution and temporal variation of nitrate nitrogen and oxygen isotopes in the upper equatorial Pacific Ocean, Limnol. Oceanogr., 61, 14-31, 2016.

Rafter, P. A., DiFiore, P. J., and Sigman, D. M.: Coupled nitrate nitrogen and oxygen isotopes and organic matter remineralization in the Southern and Pacific Oceans, J. Geophys. Res.-Oceans, 118, 4781-4794, 2013.
Raimbault, P. and Garcia, N.: Evidence for efficient regenerated production and dinitrogen fixation in nitrogen-deficient waters of the South Pacific Ocean: impact on new and export production estimates, Biogeosciences, 5, 323-338, https://doi.org/10.5194/bg-5-323-2008, 2008.

Shiozaki, T., Kodama, T., and Furuya, K.: Large-scale impact of the island mass effect through nitrogen fixation in the western South Pacific Ocean, Geophys. Res. Lett., 41, 2907-2913, 2014.

Sigman, D. M., Casciotti, K. L., Andreani, M., Barford, C. Galanter, M., and Bohlke, J. K.: A bacterial method for the nitrogen isotopic analysis of nitrate in seawater and freshwater, Anal. Chem., 73, 4145-4153, 2001.

Sohm, J. A., Webb, E. A., and Capone, D. G.: Emerging patterns of marine nitrogen fixation, Nat. Rev. Microbiol., 9, 499-508, 2011.

Stal, L. J.: Is the distribution of nitrogen-fixing cyanobacteria in the oceans related to temperature?, Environ. Microbiol., 11, 16321645, 2009.

Stenegren, M., Caputo, A., Berg, C., Bonnet, S., and Foster, R. A.: Distribution and drivers of symbiotic and free-living diazotrophic cyanobacteria in the western tropical South Pacific, Biogeosciences, 15, 1559-1578, https://doi.org/10.5194/bg-151559-2018, 2018.

Van Den Broeck, N., Moutin, T., Rodier, M., and Le Bouteiller, A.: Seasonal variations of phosphate availability in the SW Pacific Ocean near New Caledonia, Mar. Ecol. Prog. Ser., 268, 1-12, 2004.

Van Mooy, B. A. S., Fredricks, H. F., Pedler, B. E., Dyhrman, S. T., Karl, D. M., Koblizek, M., Lomas, M. W., Mincer, T. J., Moore, L. R., Moutin, T., Rappe, M. S., and Webb, E. A.: Phytoplankton in the ocean use non-phosphorus lipids in response to phosphorus scarcity, Nature, 458, 69-72, 2009.

Weber, T. and Deutsch, C.: Local versus basin-scale limitation of marine nitrogen fixation, P. Natl. Acad. Sci. USA, 111, 87418746, 2014.

Yoshikawa, C., Makabe, A., Shiozaki, T., Toyoda, S., Yoshida, O., Furuya, K., and Yoshida, N.: Nitrogen isotope ratios of nitrate and $\mathrm{N}^{*}$ anomalies in the subtropical South Pacific, Geochem. Geophy. Geosy., 16, 1439-1448, 2015. 